\title{
Charcoal fuel from the mixture of coconut shell waste and coal: effect of carbonization temperature and the amount of coal mass in the mixture
}

\author{
Siswanto*, Kindriari Nurma Wahyusi Renova Panjaitan \\ Chemical Engineering, Engineering Faculty, Universitas Pembangunan Nasional “Veteran”, East Java, Indonesia
}

\begin{abstract}
Contributing to the solution-finding for the availability of dwindling fossil energy, this study produced charcoal fuel from a biomass mixture of coconut shell waste and coal, using adhesive from meranti wood. The research was conducted by observing the effect of the carbonization temperature parameters and the amount of coal used in the mixture on the quality of charcoal fuel. The quality was evaluated on the calorific value, water content, and ash content. In addition, the data were analyzed mathematically using the response surface methodology to determine the interaction effect of independent variables on the response and to obtain the best conditions for producing charcoal fuel with the desired quality in the variable range of carbonization temperature of $300^{\circ} \mathrm{C}-500^{\circ} \mathrm{C}$ and coal mass in the range $10-30$ grams. The results revealed that the temperature parameter had a significant effect on the calorific value, water content, and ash content. While the amount of coal mass did not significantly affect the calorific value and ash content but significantly affected the water content of charcoal fuel. The carbonization temperature and the amount of coal in the mixture of raw materials suggested were $409.625^{\circ} \mathrm{Cand} 10 \mathrm{gr}$.
\end{abstract}

Keyword : Charcoal Fuel, Coconut Shell Waste, Carbonization

\section{Introduction}

The dwindling availability of fossil fuels has become one of the research interest areas for a long time. Various endeavors have been proposed to reduce the necessity of fossil fuels by looking for alternative fuels like briquettes. Briquettes are solid fuels composed of biomass that are compressed in a mold according to the desired size. The raw material for making briquettes can be a mixture of several unprocessed biomass, agricultural waste, or former household furnishings $[1,2]$.

One of the potential resources as raw materials for briquette making is coconut shells, the rigorous part of coconut fruit that commonly ends up as waste after being separated from its copra. This biomass has a high enough calorific value beyond others biomass [3]. In addition, coconut shells are also available in large quantities, where based on data from the Directorate General of Estates since 2017 to 2019, Indonesia can produce around 2.8 million tons of coconut per year [4]. Also, the use of coconut shells as a fuel does not compete with food needs like other biomass raw materials but instead helps solve environmental issues, namely reducing organic waste that is difficult to decompose.

\footnotetext{
* Corresponding author : siswantomoenandar@gmail.com
}

The use of coconut shells as the fuel raw material has been performed by several researchers before. Maryono et.al., [5] made briquettes from coconut shells by analyzing the effect of the amount of starch adhesive. Promdee et. al., [3] analyzed the difference between activated carbon and coconut shell briquettes with starch adhesive. Rindayatno et. al., [6] produced briquette from the materials mixture of meranti and coconut shells using starch as an adhesive substance. In that research, they analyzed the difference in the ratio of the two biomass raw materials on the product. However, these briquette processes making still used starch as an adhesive substance, which is also known as tapioca flour, namely flour made from cassava which will cause the possibility of competing for the food needs. Shangdiar et. al., [7] made briquettes from a mixture of coconut shells with sewage sludge from wastewater treatment. That process was successfully carried out, but the obtained product had a calorific value that was quite far from the calorific value of the raw materials used.

Meanwhile, Morena et. al., [1] stated that besides starch, other natural compounds can act as adhesives, namely lignin. Lignin is a complex biopolymer composite containing hydroxyl, methoxyl, carbonyl, and carboxyl functional groups and can generally be found in woody biomass or seasonal plants [8-11]. One of them is meranti wood which has a lignin content of about $31.5 \%$ [12]. On the other hand, Jamilatun [13] 
stated that briquettes made from coal have a high calorific value.

Therefore, in this study, briquettes were made from a mixture of coconut shells and coal using lignin adhesive from meranti wood. In this case, the coconut shell first experienced the carbonization process. This process was carried out because the previous literature stated that the carbonization process could improve the quality of biomass properties as fuel raw materials $[2,14]$. This research was carried out by analyzing the effect of carbonization temperature and the amount of coal mass used on the calorific value, water content and ash content of the fuel briquettes or charcoal produced. Furthermore, data analysis was completed using the response surface methodology.

\section{Materials and methods}

\subsection{Materials}

Raw materials for briquette making were coconut shell waste and coal collected from Rungkut, East Java, Indonesia. The meranti woods as the adhesive base were from Mojokerto, East Java, Indonesia. It was shredded and dried in oven at temperature of $100^{\circ} \mathrm{C}$ before used. The chemical used viz $15 \% \mathrm{NaOH}$ was obtained from a local store.

\subsection{Methods}

\subsubsection{Adhesive preparation}

The shredded meranti wood was steamed for approximately 1.5 hours to soften it. Afterward, it was mixed with $15 \% \mathrm{NaOH}$ solution at a ratio of $1: 4$ (biomass to $\mathrm{NaOH}$ ) and heated for 2 hours at $100^{\circ} \mathrm{C}$. Then, it was filtered, and the filtrate was concentrated by reheating it for 2 hours.

\subsubsection{Briquettes making}

The briquette making was preceded by carbonizing the coconut shells. This process was executed by crushing the coconut shells into pieces, then put into the furnace for 2 hours. Its temperature was set according to variables of $300^{\circ} \mathrm{C}, 350^{\circ} \mathrm{C}, 400^{\circ} \mathrm{C}, 450^{\circ} \mathrm{C}, 500^{\circ} \mathrm{C}$. After that, the carbonized coconut shells and coal were grounded and sieved using a 30-mesh sieve. Then, 5 grams of coconut shell powder was weighed and mixed with coal powder and adhesive. In this research, the weight of coal was varied to $10,15,20,25$, and 30 grams, while the adhesive was $40 \%$ of the total mass of coconut shell and coal powder. The mixture was blended until well mixed, then molded using a PVC pipe with a height of $3.5 \mathrm{~cm}$ and $2 \mathrm{~cm}$ in diameter. Furthermore, the briquettes were dried in the oven at a temperature of $100^{\circ} \mathrm{C}$ for 3 hours. Then, the products were analyzed using a bomb calorimeter to get the heating value and using the gravimetric method to know the water content and the ash content

\subsubsection{Response surface analysis}

To understand more about the interaction effect of independent parameters such as the carbonized temperature of coconut shell and the mass of coal in briquette mixture on the response variables like heating value, water content, and ash content, response surface modeling was applied. The response surface model type used was Face center central composite design (FCCD) with two factors, as shown in Table 1.

Table 1. Level of factor design

\begin{tabular}{|c|c|c|c|}
\hline Factor & $\begin{array}{c}\text { Coded } \\
\text { low }\end{array}$ & Coded high & Mean \\
\hline $\begin{array}{c}\text { Temperature } \\
\left(\mathrm{A} /{ }^{\circ} \mathrm{C}\right)\end{array}$ & $-1 \rightarrow 300$ & $+1 \rightarrow 500$ & 400 \\
\hline Mass of coal (B/gr) & $-1 \rightarrow 10$ & $+1 \rightarrow 30$ & 20 \\
\hline
\end{tabular}

The modeling was using Design-Expert software, version 13-trial, Stat-Ease, Inc., Minneapolis, MN, USA, which referred to multiple regression as in Equation 1, where $\mathrm{Y}$ is response parameters (heating value, ash content or water content), $\beta_{0}$ is intercept, $\beta_{\mathrm{i}}$ is linear, $\beta_{\mathrm{ii}}$ is quadratic term, $\beta_{\mathrm{ij}}$ refers to interaction term, and $\mathrm{x}_{\mathrm{i}}$ and $\mathrm{x}_{\mathrm{j}}$ are the independent parameters, $\mathrm{k}$ is the number of parameters.

$$
Y=\beta_{0}+\sum_{i=1}^{k} \beta_{i} x_{i}+\sum_{i=1}^{k} \beta_{i i} x_{i}^{2}+\sum_{1 \leq i \leq j}^{k} \beta_{i j} x_{i} x_{j}
$$

\section{Results and Discussion}

Briquettes from a mixture of coconut shells and coal were produced using lignin adhesive from meranti wood. In this case, the lignin was extracted through the soda pulping process, heating the wood fibers using $\mathrm{NaOH}$ solution. The briquette made in this research was the super briquette, a charcoal fuel where the biomass raw material was carbonized first. The carbonization process is an incomplete combustion process of biomass without the presence of oxygen $[2,15]$. All the briquettes were analyzed in the value of heating, ash content, and water content later compared to the SNI quality.

\subsection{Heating value of charcoal fuel}

The experimental results (Figure 1) interpreted that the heating value of charcoal fuel increased with the increase in temperature from $300^{\circ} \mathrm{C}$ to $500^{\circ} \mathrm{C}$ at variables of coal mass $30,20,15$, and $10 \mathrm{gr}$. This increasing phenomenon of calorific value occurred because the carbonization process can increase the amount of carbon in the biomass [2]. An increase in the amount of carbon certainly causes an increase in the heating value of fuel [16]. Meanwhile, in the $25 \mathrm{gr}$ of coal mass, the temperature change from $350^{\circ} \mathrm{C}$ to $400^{\circ} \mathrm{C}$ prompted a decrease in calorific value. That decrease was probably due to the interaction among the independent variables and other fixed variables such as the amount of adhesive mass used or other factors such as molding pressure value. Where in this study, the molding pressure was excluded or assumed to have a low impact. Aransiola et. al., [2] mentioned that other 
factors that need to be considered in briquettes producing from biomass were adhesive concentration and molding pressure. However, even if there was a decrease, the value was not too significant compared to the increase in heating value that occurred due to the changing temperature from $300^{\circ} \mathrm{C}$ to $350^{\circ} \mathrm{C}$ and from $400^{\circ} \mathrm{C}$ to $500^{\circ} \mathrm{C}$ in the same variable of mass coal. Thus, overall, it could be concluded that the heating value increased with carbonization temperature.

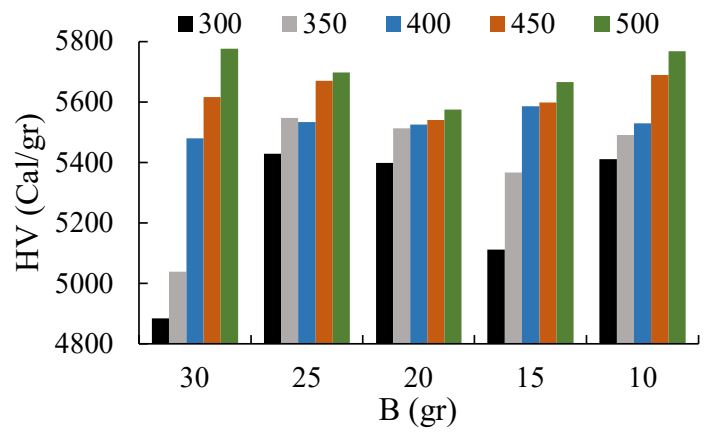

Fig. 1. The heating value of briquette at variations of carbonization temperature $\left({ }^{\circ} \mathrm{C}\right)$ and mass of coal (gr)

Besides, Figure 1 showed that the influence of coal mass in the mixture of raw materials developed quite varied phenomena on the calorific value of charcoal fuel. However, overall, the change in calorific value due to the change in coal mass was not too significant. This statement was verified by response surface data analysis which being explained in the next sub-chapter. The heating value of charcoal fuel in this research varied from 4884 to $5777 \mathrm{cal} / \mathrm{gr}$. Comparing with SNI quality, except for the product at a carbonization temperature of $300^{\circ} \mathrm{C}$ with a total coal mass of $30 \mathrm{gr}$, all of the obtained charcoal fuel met the standard calorific value, which was higher than $5000 \mathrm{cal} / \mathrm{gr}$ [6].

\subsection{Ash content of charcoal fuel}

Ash is the residue of combustion that no longer contains carbon elements. The ash content of charcoal fuel was presented in Figure 2 as a function of the mass of coal verse the percentage value of ash at the varied conditions of carbonized temperature. That graph displayed that the ash content of charcoal fuel in all conditions of coal mass variables experienced an increasing phenomenon along with the increase in carbonization temperature from $300^{\circ} \mathrm{C}$ to $500^{\circ} \mathrm{C}$. That trend happened because the carbonization process at higher temperatures caused a critical devolatilization which certainly not only experienced by organic compounds but also inorganic compounds of that biomass. That extreme devolatilization process of inorganic compounds contributed to the increase in ash content [17]. Besides, Osei Bonsu et. al., mentioned that the amount of ash in biomass depends on its organic and inorganic compounds [18]. In addition, it also was supported by research conducted by Zajac et. al., [19]. In that study, they analyzed the effect of combustion temperature of some biomass on the composition of the ash produced.
They reported that even though the overall amount of biomass ash decreased with the increase in combustion temperature, some ash elements experienced the yield increasing such as $\mathrm{Cr}, \mathrm{Ni}$, and $\mathrm{Fe}$, as an effect of the temperature increasing. Where one of the constituents in coconut shell ash reported was iron compounds in the form of oxides [20].

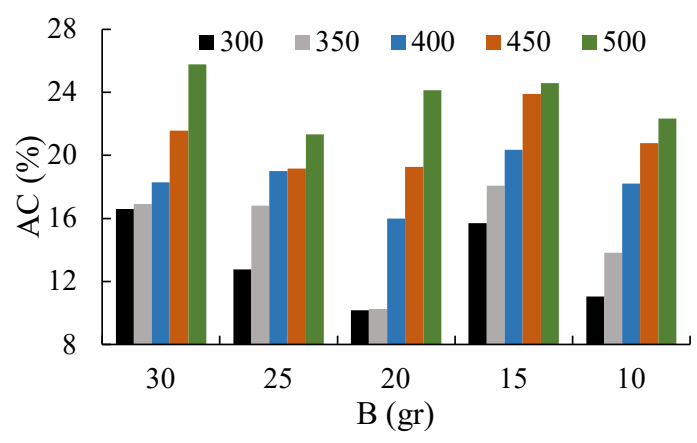

Fig. 2. Ash content of briquette at variations of carbonization temperature $\left({ }^{\circ} \mathrm{C}\right)$ and mass of coal (gr)

Figure 2 also pointed that the value of the ash content of the charcoal fuel varied from $10.1899 \%$ to $25.7658 \%$. This percentage was high, where the amount of ash content in charcoal fuel is preferable in low amounts. Based on SNI, the percentage value is not more than $8 \%$ [21]. Thus, the charcoal fuel in this study did not meet that standard. The high ash content in the charcoal fuel of this experiment might be affected by the composition of the compounds in raw materials of meranti wood and coal. Where Yuniarti et. al., [22] conducted a study on the production of briquettes using meranti wood and glam wood at various mass ratios, and they reported that at a variable of one hundred percent of meranti wood, briquette had the highest value of ash content. That phenomenon revealed that meranti wood has the potential to contribute to the ash content of charcoal fuel. In addition, Triwulan et. al., [23] reported that coal contained high minerals, one of which was iron oxide considered to supply the ash content. Thus, in the manufacture of charcoal fuel from a mixture of coconut shells and coal with meranti wood as an adhesive, it is necessary to handle the raw materials or the briquette to reduce the ash content because the high ash content in the fuel can produce cinder on the equipment.

\subsection{Water content of charcoal fuel}

The moisture content of charcoal fuel affects the ignited process of the charcoal, where charcoal with a highwater content will be difficult to burn because much more heat is needed to evaporate the water first [2]. Therefore, the low water content in charcoal fuel was preferable. In this research, as shown in Figure 3, the higher the carbonization temperature, stated from $300^{\circ} \mathrm{C}$ to $500^{\circ} \mathrm{C}$ at every value of coal mass variable $(10,15$, $20,25$, and $30 \mathrm{gr})$, the lower the charcoal water content. This tendency was due to heating in the carbonization process caused evaporation of water content in the biomass material. Therefore, the higher the 
carbonization temperature in the same length of time, the more water evaporated. The same trend also was reported by Siahaan et. al., [15] while making charcoal from rice husks.

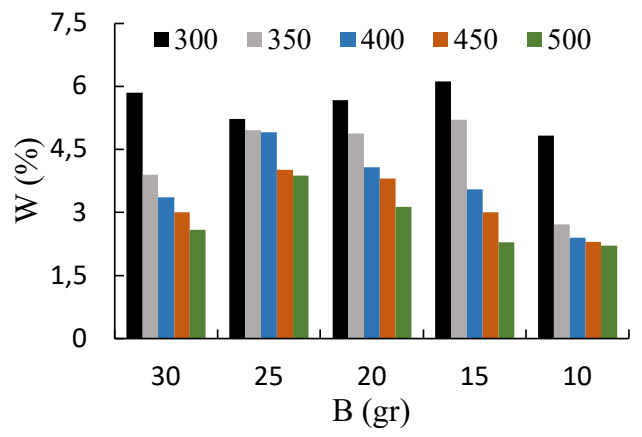

Fig. 3. Water content of briquette at variations of carbonization temperature $\left({ }^{\circ} \mathrm{C}\right)$ and mass of coal (gr)

Meanwhile, the amount of coal mass in raw material composition caused a varied tendency in water content, but generally, the higher its value, the higher the water content of charcoal fuel. This trend might be because of the hygroscopic character of coal. Furthermore, the charcoal fuel quality in this research, based on the water content aspect, met the SNI standard, namely lower than $8 \%[21]$.

\subsection{Response surface analysis}

Response surface analysis conducted in this study aimed to analyze the interaction effect of parameters in the response variable. Moreover, assisting in concluding the best operation condition of the charcoal fuel-making on variations of the carbonization temperature and weight of coal in the charcoal mixture. Determining the best condition referring to the one-factor-at-a-time analysis can produce inaccurate values caused by the possibility of an interaction between the independent parameters on the response parameters [24]. This research has carried out surface response analysis in 9 runs, including one center points, as shown in Table 2.

Table 2. Experimental design of FCCD

\begin{tabular}{|c|c|c|c|c|c|}
\hline \multirow[b]{2}{*}{ Run } & \multirow[b]{2}{*}{$\begin{array}{c}\mathbf{A} \\
\left({ }^{\circ} \mathrm{C}\right)\end{array}$} & \multirow[b]{2}{*}{$\begin{array}{l}\text { B } \\
\text { (gr) }\end{array}$} & \multicolumn{3}{|c|}{ Response parameters } \\
\hline & & & $\begin{array}{c}\text { HV } \\
\text { (Cal/gr) }\end{array}$ & $\begin{array}{l}\mathrm{AC} \\
(\%)\end{array}$ & $\begin{array}{l}W \\
(\%)\end{array}$ \\
\hline 1 & 400 & 30 & 5480 & 18.2768 & 3.366 \\
\hline 2 & 300 & 30 & 4884 & 16.5916 & 5.8481 \\
\hline 3 & 500 & 10 & 5768 & 22.3329 & 2.2048 \\
\hline 4 & 500 & 30 & 5777 & 25.7658 & 2.5885 \\
\hline 5 & 300 & 20 & 5398 & 10.1899 & 5.6736 \\
\hline 6 & 300 & 10 & 5411 & 11.0591 & 4.827 \\
\hline 7 & 500 & 20 & 5575 & 24.115 & 3.1307 \\
\hline 8 & 400 & 20 & 5525 & 15.988 & 4.0702 \\
\hline 9 & 400 & 10 & 5529 & 18.2188 & 2.403 \\
\hline \multicolumn{6}{|c|}{$\begin{array}{ll}\text { Note : } & \\
\mathrm{A} \quad \text { : carbonization temperature } & \mathrm{AC}: \text { ash content } \\
\mathrm{B} \quad \text { : mass of coal } & \mathrm{W}: \text { water content } \\
\mathrm{HV}: \text { heating value } & \end{array}$} \\
\hline
\end{tabular}

From data analysis using multiple regression equations was found that the appropriate model for response heating value and ash content was linear, while for water content was a quadratic model. The model equations in coded form for each response are in Equations 2, 3, and 4, where $\mathrm{Y}_{\mathrm{HV}}, \mathrm{Y}_{\mathrm{AC}}, \mathrm{Y}_{\mathrm{w}}$ are heating value, ash content, and water content, respectively. The sign of the parameters in these equations indicated its effect on the response value. According to the equations, parameter A-carbonized temperature had a positive sign on Equation 2 and 3 but a negative sign on Equation 4. It means parameter A positively affected the heating value and the ash content, but it negatively affected the water content. Or in another way, the higher the carbonized temperature, the higher the heating value and ash content of charcoal fuel, but conversely lowering the water content. It confirmed the statement in the previous sub-chapter. Meanwhile, parameter B-mass off coal had a negative sign on the equation of the heating value (Eq.2) but had a positive effect on the ash and water content equation (Eq. 3 \& Eq.4). It verified that rising the coal mass value could increase the value of ash content and water content but contrarily would decrease the heating value. In addition, Equation 4 showed that the interaction parameter between the carbonization temperature parameter and coal mass $(\mathrm{AB})$ had a negative sign, as well as the square of the coal mass parameter $\left(\mathrm{B}^{2}\right)$, while the square form of the carbonization temperature $\left(\mathrm{A}^{2}\right)$ had a positive term in the equation. Thus, it informed that to control the water content of charcoal fuel, the quadratic value of these parameters needs to be considered.

$$
\begin{aligned}
Y_{H V} & =5483+237.833 A-94.5 B \\
Y_{A C} & =18.0598+ \\
Y_{W} & =3.72885 A+1.5039 B \\
& \quad+0.765717 A^{2}-0.75193 B^{2}
\end{aligned}
$$

All the model equations were feasible enough to represent the actual phenomenon, shown by the significance of the model $\mathrm{p}$-value $(\mathrm{p}$-value $<0.05)$ and the coefficient determination ( $\mathrm{R}^{2}$ close to one) [25]. Based on the data in Table 3, the p-value of the linear model for heating value and ash content and quadratic model for water content response was lower than 0.05 , which indicated that those models were significant to represent the actual condition with only $2.37 \%, 0.08 \%$, and $0.75 \%$ chance that F-value of $7.45,29.67$, and 34.53 for the model of heating value, ash content and water content, respectively, occurred due to noise. The $\mathrm{R}^{2}$ of the three-model response was near to one, wherein number was $0.713,0.9082$, and 0.9829 , respectively, it indicated the feasibility of the reliable model.

Furthermore, the analysis data in Table 3 displayed that the carbonized temperature significantly affected all the parameters response ( $p$-value $<0.05$ ). While the weight of coal used did not significantly affect the response heating value and the ash content ( $p$-value $>0.05$ ) but had a significant effect on water content. In addition, the ANOVA data showed that the quadratic term of the temperature $\left(\mathrm{A}^{2}\right)$ and coal mass $\left(\mathrm{B}^{2}\right)$ parameters had a significant effect on the water content response with a p-value of 0.0354 and 0.0371, 
respectively. While the interaction term of carbonized temperature and mass of coal (AB) insignificantly effected the water content.

Table 3. Model Analysis of variance (ANOVA)

\begin{tabular}{|c|c|c|c|c|c|}
\hline Source & $\begin{array}{c}\text { Sum } \\
\text { of } \\
\text { square } \\
\text { s } \\
\end{array}$ & $\begin{array}{l}\mathbf{d} \\
\mathbf{f}\end{array}$ & $\begin{array}{c}\text { Mean } \\
\text { squar } \\
\text { e }\end{array}$ & F-value & $\begin{array}{c}\text { p- } \\
\text { value }\end{array}$ \\
\hline \multicolumn{6}{|c|}{ Response 1: Heating value } \\
\hline Model & $\begin{array}{c}3.93 \mathrm{E}+ \\
05\end{array}$ & 2 & $\begin{array}{c}1.97 \mathrm{E} \\
+05\end{array}$ & 7.45 & 0.0237 \\
\hline $\begin{array}{c}\text { A- } \\
\text { Temperatu } \\
\text { re }\end{array}$ & $\begin{array}{c}3.39 \mathrm{E}+ \\
05\end{array}$ & 1 & $\begin{array}{c}3.39 \mathrm{E} \\
+05\end{array}$ & 12.87 & 0.0115 \\
\hline $\begin{array}{c}\text { B-Mass of } \\
\text { Coal }\end{array}$ & $\begin{array}{c}53581 . \\
5\end{array}$ & 1 & $\begin{array}{c}53581 . \\
5\end{array}$ & 2.03 & 0.204 \\
\hline Residual & $\begin{array}{c}1.58 \mathrm{E}+ \\
05\end{array}$ & 6 & $\begin{array}{c}26375 . \\
72 \\
\end{array}$ & & \\
\hline Cor Total & $\begin{array}{c}5.51 \mathrm{E}+ \\
05\end{array}$ & 8 & & & \\
\hline \multicolumn{6}{|c|}{$\mathrm{R}^{2}=0.713 ;$ Adjusted $\mathrm{R}^{2}=0.617$} \\
\hline \multicolumn{6}{|c|}{ Response 2: Ash content } \\
\hline Model & 210.49 & 2 & 105.24 & 29.67 & 0.0008 \\
\hline $\begin{array}{c}\mathrm{A}- \\
\text { Temperatu } \\
\text { re } \\
\end{array}$ & 196.92 & 1 & 196.92 & 55.51 & 0.0003 \\
\hline $\begin{array}{c}\text { B-Mass of } \\
\text { Coal }\end{array}$ & 13.57 & 1 & 13.57 & 3.83 & 0.0983 \\
\hline Residual & 21.28 & 6 & 3.55 & & \\
\hline Cor Total & 231.77 & 8 & & & \\
\hline \multicolumn{6}{|c|}{$\mathrm{R}^{2}=0.9082 ;$ Adjusted $\mathrm{R}^{2}=0.8776$} \\
\hline \multicolumn{6}{|c|}{ Response 3: Water content } \\
\hline Model & 15.17 & 5 & 3.03 & 34.53 & 0.0075 \\
\hline $\begin{array}{c}\text { A- } \\
\text { Temperatu } \\
\text { re }\end{array}$ & 11.83 & 1 & 11.83 & 134.63 & 0.0014 \\
\hline $\begin{array}{c}\text { B-Mass of } \\
\text { Coal }\end{array}$ & 0.9344 & 1 & 0.9344 & 10.63 & 0.0471 \\
\hline $\mathrm{AB}$ & 0.1016 & 1 & 0.1016 & 1.16 & 0.3611 \\
\hline $\mathrm{A}^{2}$ & 1.17 & 1 & 1.17 & 13.35 & 0.0354 \\
\hline $\mathrm{B}^{2}$ & 1.13 & 1 & 1.13 & 12.87 & 0.0371 \\
\hline Residual & 0.2636 & 3 & 0.0879 & & \\
\hline Cor Total & 15.43 & 8 & & & \\
\hline
\end{tabular}

For more details, the correlation among the independent parameters and the response parameters was presented by 3D plots in Figures 4, 5, and 6. Using a $3 \mathrm{D}$ plot, the changing effect of two parameters, at the same time, on the response parameter value can be analyzed [25]. The changing value is represented by the color gradation of contour, and for this study, the higher the response value, the redder the contour color. In Figure 4, the increase in temperature with the decrease in coal mass caused the increase in the heating value. Figure 5 showed that the temperature decrease accompanied by the decrease in coal mass caused the decline in the value of ash content. Figure 6 expressed that there was a curve on the correlation among the parameters. From these three 3D graphs, we can see that the optimum conditions of carbonized temperature and coal mass have not been obtained yet, in the range of parameter level design (Table 1). It might happen because the range values of parameter levels were too large or vice versa. Generally, reducing or increasing the range level of the design parameters can resolve this case.

Nevertheless, the modeling in this study can still get the best conditions of carbonized temperature and mass coal to obtain the charcoal fuel with the preferable quality, maximum heating value, and minimum value of ash and water content. The suggested conditions for the used range level design were at a carbonization temperature of $409.625^{\circ} \mathrm{C}$ and a coal mass of $10 \mathrm{gr}$.

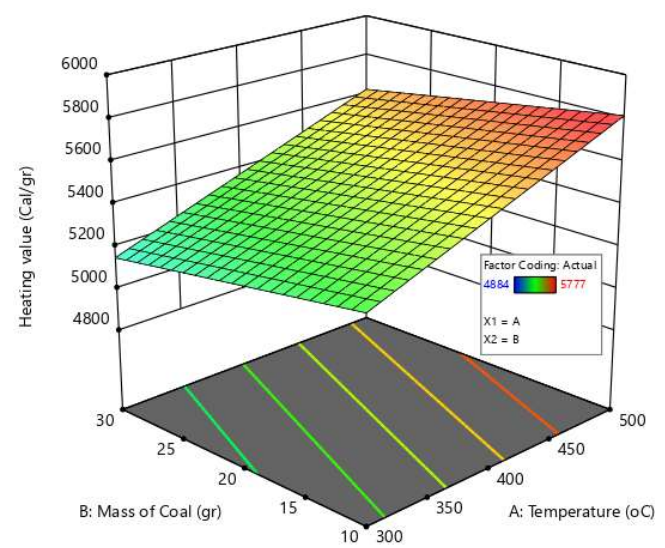

Fig. 4. Plot $3 \mathrm{D}$ of the response heating value model

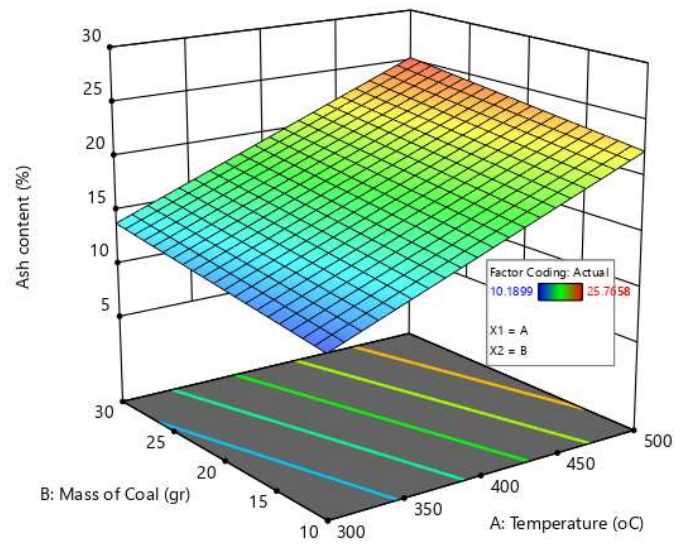

Fig. 5. Plot 3D of the response ash content model

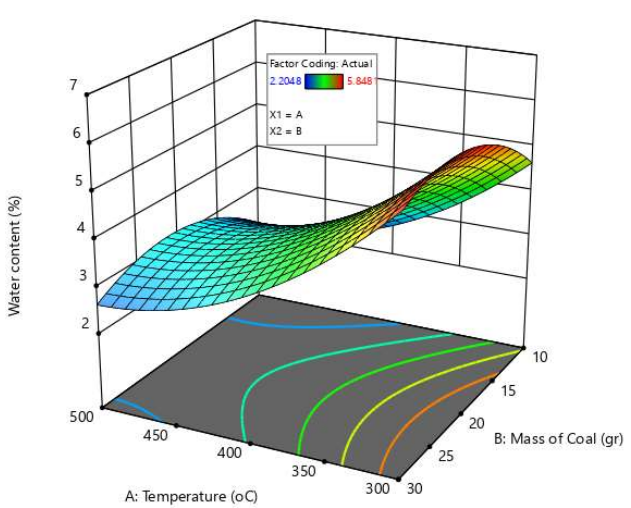

Fig. 6. Plot $3 \mathrm{D}$ of the response water content model 


\section{Conclusion}

In the process of charcoal fuel-making from a mixture of coconut shells and coal with lignin from meranti wood as an adhesive, based on the response surface analyzed, the carbonization temperature of coconut shells significantly affected the heating value, water content, and ash content. The higher the carbonization temperature, the heating value and ash content increased, while the water content decreased. Meanwhile, the amount of coal mass did not significantly affect the caloric value and ash content but did significantly affect the water content of charcoal fuel. In addition, the quadratic term of the temperature parameter and the amount of coal mass in the raw material mixture significantly affected the water content of the product. The temperature values and the amount of coal mass suggested in the range of variables used in this study were $409.625^{\circ} \mathrm{C}$ and $10 \mathrm{gr}$, respectively.

\section{References}

1. A. I. Moreno, R. Font, and J. A. Conesa, Waste Manag. 49, 245 (2016).

2. E. F. Aransiola, T. F. Oyewusi, J. A. Osunbitan, and L. A. O. Ogunjimi, Energy Reports 5, 909 (2019).

3. K. Promdee, J. Chanvidhwatanakit, S. Satitkune, C. Boonmee, T. Kawichai, S. Jarernprasert, and T. Vitidsant, Renew. Sustain. Energy Rev. 75, 1175 (2017).

4. D. G. of Estate, (n.d.).

5. Maryono, Sudding, and Rahmawati, J. Chem. 14, 74 (2013).

6. Rindayatno, M. K. Sari, and S. Wagiman, Pros. Semin. Nas. I Balai Ris. Dan Stand. Ind. Samarinda 98 (2017).

7. S. Shangdiar, Y. C. Lin, P. C. Cheng, F. C. Chou, and W. D. Wu, Energy 215, 119151 (2021).

8. R. V. Gadhave, P. S. Kasbe, P. A. Mahanwar, and P. T. Gadekar, Int. J. Adhes. Adhes. 95, 102427 (2019).

9. Z. Guo, J. Wu, Y. Zhang, K. Cao, Y. Feng, J. Liu, and Ji. I. Li, Fuel 267, 117260 (2020).

10. S. Feng, T. Shui, H. Wang, X. Ai, T. Kuboki, and C. C. Xu, Ind. Crops Prod. 161, 113225 (2021).

11. S. Laurichesse and L. Avérous, Prog. Polym. Sci. 39, 1266 (2014).

12. R. Amirta, E. Herawati, W. Suwinarti, and T. Watanabe, Agric. Agric. Sci. Procedia 9, 202 (2016).

13. S. Jamilatun, J. Rekayasa Proses 2, 37 (2008).

14. W. Nuriana, N. Anisa, and Martana, Energy Procedia 47, 295 (2014).

15. S. Siahaan, M. Hutapea, and R. Hasibuan, J. Tek. Kim. USU 2, 26 (2013).

16. L. D. B. Pestaño and W. I. Jose, Int. J. Renew. Energy Dev. 5, 187 (2016).

17. N. Gómez, S. W. Banks, D. J. Nowakowski, J. G. Rosas, J. Cara, M. E. Sánchez, and A. V. Bridgwater, Fuel Process. Technol. 172, 97 (2018).

18. B. Osei Bonsu, M. Takase, and J. Mantey, Heliyon 6, e05266 (2020).

19. G. Zajac, J. Szyszlak-Bargłowicz, and M.
Szczepanik, Appl. Sci. 9, (2019).

20. M. G. Voronkov and V. E. Udre, Chem. Heterocycl. Compd. 1, 458 (1965).

21. H. Roliadi and G. Pari, Indones. J. For. Res. 3, 93 (2006).

22. Y. Yuniarti, J. Ris. Ind. Has. Hutan 3, 38 (2011).

23. Triwulan, K. A. Priadana, J. J. Ekaputri, and R. Bayuaji, IOP Conf. Ser. Mater. Sci. Eng. 267, (2017).

24. Z. Wahid and N. Nadir, World Appl. Sci. J. 21, 56 (2013).

25. R. Panjaitan, M. Mahfud, E. D. Cahyati, and L. Pujaningtyas, IOP Conf. Ser. Earth Environ. Sci. 749, 012032 (2021). 